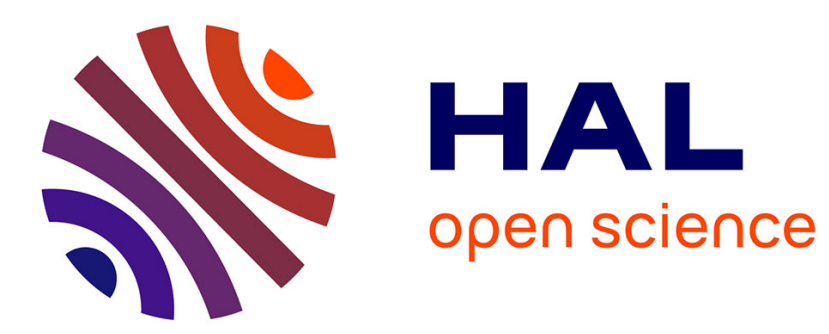

\title{
Inversion sexuelle et monde à l'envers dans la littérature pamphlétaire de la Révolution anglaise (1640-1660)

\author{
Claire Gheeraert-Graffeuille
}

\section{To cite this version:}

Claire Gheeraert-Graffeuille. Inversion sexuelle et monde à l'envers dans la littérature pamphlétaire de la Révolution anglaise (1640-1660). XVII-XVIII Revue de la Société d'études anglo-américaines des XVIIe et XVIIIe siècles , 1998, 47 (1), pp.133-151. 10.3406/xvii.1998.1409 hal-02060485

\section{HAL Id: hal-02060485}

\section{https://hal-normandie-univ.archives-ouvertes.fr/hal-02060485}

Submitted on 7 Mar 2019

HAL is a multi-disciplinary open access archive for the deposit and dissemination of scientific research documents, whether they are published or not. The documents may come from teaching and research institutions in France or abroad, or from public or private research centers.
L'archive ouverte pluridisciplinaire HAL, est destinée au dépôt et à la diffusion de documents scientifiques de niveau recherche, publiés ou non, émanant des établissements d'enseignement et de recherche français ou étrangers, des laboratoires publics ou privés. 


\section{Inversion sexuelle et monde à l'envers dans la littérature pamphlétaire de la Révolution anglaise (1640-1660)}

In: XVII-XVIII. Bulletin de la société d'études anglo-américaines des XVIle et XVIIle siècles. N47, 1998. pp. 133151.

Citer ce document / Cite this document :

Gheeraert-Grafeuille Claire. Inversion sexuelle et monde à l'envers dans la littérature pamphlétaire de la Révolution anglaise (1640-1660). In: XVII-XVIII. Bulletin de la société d'études anglo-américaines des XVIle et XVIIle siècles. №47, 1998. pp. 133151.

doi : $10.3406 / x v i i .1998 .1409$

http://www.persee.fr/web/revues/home/prescript/article/xvii_0291-3798_1998_num_47_1_1409 


\section{INVERSION SEXUELLE ET MONDE À L'ENVERS DANS LA LITTÉRATURE PAMPHLÉTAIRE DE LA RÉVOLUTION ANGLAISE (1640-1660)}

Pendant la Révolution anglaise, les chroniqueurs constatent avec stupeur le rôle nouveau joué par les femmes dans les domaines politique et religieux. Antonia Fraser, friande de ces récits, évoque les femmes qui défendent les châteaux assiégés, les pétitionnaires qui se pressent aux portes du Parlement ou encore les prophétesses exaltées qui annoncent l'avènement de la Cinquième Monarchie. ${ }^{1}$ Bien que ces figures exceptionnelles arent eu quelques défenseurs, les réactions hostiles dominent largement l'abondante littérature pamphlétaire que nous ont laissée deux décennies de révolution. L'une des stratégies, utilisées par les pamphlétaires pour neutraliser la menace que représente l'irruption de ces figures hors-normes, consiste à recourir au motif traditionnel du monde à l'envers dont l'inversion des rôles sexuels est une manifestation caractéristique. ${ }^{2}$ À partir d'un corpus de pamphlets et de gazettes, nous nous proposons d'étudier, dans une perspective thématique, cette symbolique d'inversion sexuelle et ses implications politiques.

Avant de commencer cette étude, il convient de rappeler brièvement les enjeux de l'idéologie patriarcale qui structure alors l'ensemble des représentations sociales et qui suppose la soumission des femmes dans la famille et, par extension, dans toute la société. ${ }^{3}$ Le premier fondement de

1. Antonia Fraser, The Weaker Vessel: Woman's Lot in Seventeenth-Century England (London: Weidenfeld and Nicoslon, 1984). La deuxième partie ("With the War Stronger Grown") est consacrée aux femmes de la Révolution anglaise.

2. Sur les représentations du monde à l'envers, voir Frédérick Tristan, Le Monde à l'envers (Paris: Hachette, 1980); Barbara A. Babcock, ed., The Reversible World: Symbolic Inversion in Art and Society (Ithaca: Cornell UP, 1971); Maurice Lever, "Le Monde à l'envers," Le Vieux Papier 29.276 (1980): 37-44: Roger Chartier and Dominique Julia, "Le Monde à l'envers," L'Arc 65 (1976): 43-53.

3. Voir en particulier Anthony Fletcher, "Men's Dilemma: The Future of Patriarchy in England 1560-1660," Transactions of the Royal Historical Society 4 (1994): 61-81; 
cette subordination se trouve dans la Genèse: "thy desire shall be to thy husband, and he shall rule over thee" (3.16). ${ }^{4}$ De cet épisode biblique, les pasteurs infèrent bien sûr l'inégalité des sexes dans le mariage chrétien, mais aussi la soumission sociale de la femme, moralement incapable de résister à ses passions. ${ }^{5}$ Le second pilier sur lequel s'appuie l'idéologie patriarcale est le discours médical qui inscrit l'infériorité de la femme dans la nature et dans le cosmos: malgré les progrès de l'anatomie, on explique encore communément que l'infériorité des femmes est due à leurs humeurs froides et humides. ${ }^{6}$ Faible physiquement et fragile psychologiquement, la femme est par conséquent bannie d'une scène publique qui exige raison et maîtrise de soi. Cette exclusion est abondamment confirmée par le recours à la pensée analogique, encore vivace au milieu du XVIIe siècle: la conception de la famille comme modèle de l'État implique à la fois le confinement de la femme à des activités strictement domestiques et sa mise à l'écart du politique. ${ }^{7}$ Toutefois, qui dit inégalité et hiérarchie dit aussi la possibilité de subvertir cette inégalité et de renverser cette hiérarchie. Et si la femme, par définition incapable de se gouverner, échappe à la tutelle masculine, la porte est ouverte à toutes les anarchies, non seulement familiales, mais aussi, par analogie, politiques et mêmes cosmiques - au moins dans l'imaginaire collectif. D'où les terreurs fantasmatiques que

Fletcher. Gender, Sex and Subordination in England 1500-1800 (New Haven: Yale UP, 1995) xv-xxii.

4. Voir John Brinsley, A Looking-Glass for Good Women (London, 1645) 39 [STC B4717] et aussi les manuels et les sermons sur le mariage, moins polémiques, mais largement diffusés.

5. Sur ces questions, voir Ian Maclean, Renaissance Notion of Woman (Cambridge: Cambridge UP, 1980) 17-19.

6. Fletcher, Gender. Sex and Subordination, surtout les chapitres 3 et 4; Thomas Laqueur, Making Sex: Body and Gender from the Greeks to Freud (Cambridge, MA: Harvard UP. 1990). Pour un exemple de cette vision humorale et cosmologique de l'infériorité féminine, voir par exemple Alexander Ross, Arcana Microcosmi: or. The Hidden Secrets of Mans Body Disclosed (London, 1651) 86 [STC R1946].

7. Sur la pensée politique du patriarcat, voir Gordon J. Schochet, Patriarchalism in English Political Thought: The Authoritarian Family and Political Speculation and Attitudes Especially in Seventeenth-Century England (Oxford: Blackwell, 1975); sur l'analogie entre la famille et l'état, voir Susan D. Amussen, "Gender, Family and the Social Order, 1560-1725," Order and Disorder in Early Modern England, ed. Fletcher and John Stevenson (Cambridge: Cambridge UP, 1985) 196-248 et Amussen, An Ordered Society: Gender and Class in Early Modern England (Oxford: Blackwell, 1988). Sur l'importance de l'argument paternel dans la justification de l'exclusion des femmes du gouvernement, voir Pierre Ronzeaud, "La Femme au pouvoir ou le monde à l'envers," XVIIe siècle 108 (1975): 9-35. 
suscitent les subversions de l'ordre des sexes. D'où aussi l'idée, illustrée dans l'iconographie du monde à l'envers, que l'échange des rôles sexuels renverse l'ordre du monde. Ainsi dans la gravure typique, El mondo al revés, ce motif figure au milieu d'autres formes d'inversion: à droite, la femme qui porte le mousquet côtoie des navires qui voguent sur la terre tandis qu'à gauche, un enfant corrige ses parents. ${ }^{8}$ Cette thématique du monde à l'envers, qui ne se limite pas d'ailleurs à l'iconographie, est souvent reprise par les royalistes pendant la Révolution pour déplorer la désolation des temps: mais il serait inexact de la limiter à ces quelques pamphlets et ballades qui entonnent le refrain: "Yet let's be content, and the times lament, / You see the world turn'd upside down. ${ }^{19}$ Le spectre du monde à l'envers dépasse en effet largement les images folkloriques d'inversion: il constitue un cadre plus large à l'intérieur duquel les polémistes interprètent toutes les formes de déviance comme des menaces de désordre politique. Ce sont ces réactions suscitées par les manifestations des pétitionnaires londoniennes qui nous intéresseront d'abord. Mais le motif de l'inversion sexuelle ne sert pas seulement à dénoncer l'activisme de quelques femmes: nous verrons dans un deuxième temps comment les satiristes de tous bords l'utilisent de façon beaucoup plus large pour stigmatiser l'ennemi politique - y compris masculin.

L'irruption de femmes pétitionnaires sur la scène londonienne n'est pas vue d'un bon œil par la plupart des pamphlétaires qui estiment que les femmes usurpent de façon illégitime des rôles uniquement masculins. ${ }^{10}$

8. Cette gravure est reproduite dans L'Image du monde renversé et ses représentations littéraires et para-littéraires de la fin du XVIe siècle au milieu du XVIIe siècle, ed. Jean Lafond and Augustin Redondo, Actes du colloque de l'université de Tours (Paris: Vrin, 1979), entre les pages 32 et 33. On trouve également cette gravure dans Tristan 92.

9. The World Is Turned Upside Down (London, 1646) [STC W3588]; sur la vision royaliste de la confusion des temps, voir Line Cottegnies, L'Éclipse du regard. La Poésie anglaise du baroque au classicisme (Genève: Droz, 1997) 224-36.

10. Sur l'activité des femmes pétitionnaires, voir Ellen McArthur, "Women Petitioners and the Long Parliament," English Historical Review 24 (1908): 698-709; Patricia Higgins, "The Reaction of Women," Politics, Religion and the English Civil War, ed. Brian Manning (London: Arnold, 1973) 179-222; Ann Marie McEntee, "The [Un]CivilSisterhood of Oranges and Lemons': Female Petitioners and Demonstrators, 1642-53," Pamphlet Wars, Prose in the English Revolution, ed. James Holstun (Buffalo: Franck Cass, 1992) 92-111; Margaret George, Women in the First Capitalist Society: Experiences in Seventeenth-Century England (Brighton: Harvester, 1989) 37-91; Ann Hughes, "L'Action des femmes dans les Révolutions anglaises," L'Encyclopédie politique des femmes, ed. Christine Fauré (Paris: PUF, 1997) 97-118. 
Une somme sur les droits du sexe féminin publiée en 1632 rappelle que les femmes n'ont pas à faire entendre leurs voix au Parlement: "women have no voice in Parliament. They make no lawes, they consent to none, they abrogate none. All of them are understood either married or to be married and their desires are subject to their husbands. . . The common law here shaketh hand with divinity." "' Dans ce contexte, il n'est pas surprenant que, dans une écrasante majorité, ${ }^{12}$ les gazettes, ou new'sbooks, qui rapportent au jour le jour les événements de la Révolution, utilisent les images conventionnelles du monde à l'envers pour dénigrer l'incursion de la femme sur la scène publique. Ainsi au printemps 1649, lorsque les femmes Niveleuses envoient au Parlement une pétition pour défendre leurs droits et tenter de faire libérer leurs maris emprisonnés, ${ }^{13}$ les journalistes de tous bords rapportent avec délectation le message des chambres qui refusent de donner suite à leurs revendications et qui les renvoient à leur cuisine:

The House having information that the Petitioners waited at the door for the Answer to their Petition, this Answer was returned them by the Serjeant at Arms by word of mouth thus;

You that are the women Petitioners, Mr Speaker, by direction of the House, hath commanded me to tell you, That the matter you petition about is of an higher concernment then you understand, that the House gave an answer to your husbands; and therefore that you are desired to go home, and look after your owne business, and meddle with vour huswiferv. ${ }^{14}$

Ce refus d'entendre les femmes est largement entériné par les journalistes qui renchérissent sur le message des chambres. Par exemple, le chroniqueur des Continued Heads déclare: "It is better for thee to be washing your

11. T. E., The Lawes Resolution of Womens Rights (1632), reproduit dans Renaissance Woman: Constructions of Femininity in England, ed. Kate Aughterson (London: Routledge. 1995) 153.

12. Si les premières manifestations et pétitions de 1642 sont relativement tolérées, les appels à la paix de 1643, puis les revendications des femmes Niveleuses en 1647, 1649,1651 et 1653 sont globalement très mal reçues par journalistes et pamphlétaires.

13. Il s'agit notamment de John Lilburne, de William Walwyn et de Richard Overton.

14. A Modest Narrative (21-28 April 1649): 29. Tous les newsbooks se font l'écho de cet événement; voir par exemple par ordre chronologique, England's Moderate Messenger (23-30 April 1649): 3: The Man in the Moon (23-30 April 1649): 22; Mercurius Pragmaticus (For King Charles I) (24 April-1 May 1649): 10; Mercurius Elencticus (24 April-1 May 1649): 5-6: The Kingdomes Weekly Intelligencer (24 April-1 : Tay 1649): 1339; A Modest Narrative of Intelligence (5-12 May 1649): 42; Mercurius Pragmaticus (8-15 May 1649): sig. D3r. 
dishes and meddle with the wheele and the distaffe": ${ }^{15}$ il n'hésite pas non plus à rappeler un peu plus loin les conséquences funestes d'un gouvernement tombé en quenouille: "That is as much as to say let women wear the breeches." $\dot{A}$ cette vieille idée s'ajoute l'argument que les femmes n'ont pas l'entendement nécessaire pour manier la parole politique. Le même auteur affirme un peu plus loin: "It can't be a good world when women meddle in State matters. If their tongues must be pratling, they may finde other talke. And their Husbands are to blame, that they have no fitter employment for them." La parole des femmes. lorsqu'elle n'est pas contrôlée par une instance masculine. perd toute dimension rationnelle et devient synonyme de tous les dérèglements. De cette façon. si les femmes votaient des lois, elles seraient forcément désastreuses: "We shall have things brought to a fine passe. if women come to teach the Parliament how to make Lawes." C'est pourquoi. pour conjurer le danger de cette parole féminine, de nombreux polémistes vont chercher à persuader leurs lecteurs de son absurdité. Certains les comparent sur le ton burlesque à des amazones dont l'arme n'est pas le fusil mais le langage: "even the women are marching down in Batalia to give the Members of Westminster a second charge, with the artillery of a Petition. ${ }^{16}$ D'autres accusent les femmes cette fois encore assimilées à des amazones - de détourner le discours des Niveleurs de son but politique en l'utilisant à des fins purement sexuelles:

who can desire more then the gallant free-borne Levellers have now obtayned, viz. to have whole Troopes of Amazons, who came in their warlike posture. taking hold of their Tavles in stead of their Targets, and marching with confidence to encounter Tyrannie, and with abundance of courage exceeding the ordinary sort of Women. demanding high terms Freedome for their Levelling Brethren, and as the Proverb goes of the Female Sex. they make use of their Tongues (as their best weapon) against tyranny. and their Tavles for propagation of the new Saynted Fraternity. ${ }^{17}$

Enfin, un certain nombre d'autres journalistes tentent de neutraliser la parole subversive de ces pétitionnaires. Ainsi les chroniqueurs hostiles aux

15. Toutes les citations qui suivent sont extraites de Contimued Heads: or: Perfect Passages in Parliament (20-27 April 1649) sig. B2 ${ }^{v}$

16. Mercurius Pragmaticus (for the Return of King Charles II) (May 1649): 32.

17. Mercurius Pragmaticus (24 April-1 May 1649): sig. Qqq2vi de façon similaire $A$ Modest Narrative donne une version ambiguë des motivations des pétitionnaires: "But observe, that some being asked, whether they petitioned for their husbands: made answer, It was for some as dear to them as their husbands" (A Modest Narrative of Intelligence [21-28 April 1649]: 29). 
manifestations pour la paix les 9 et 10 août 1643, insistent sur la basse extraction et les mœurs douteuses d'un grand nombre de manifestantes. C'est le cas du Kingdomes Weekly Intelligencer qui suggère que la pauvreté et l'absence de moralité des manifestantes sont incompatibles avec une action politique raisonnable: ${ }^{18}$ la peur de la populace prend ici une dimension sexuée: "for you must know (except some few women) these women were for the most part, Whores, Bawdes, Oyster-women, Kitchen-stuffe women, beggar women, and the very scum of the Suburbs, besides an abundance of Irish women." 19 Pour discréditer ces manifestations féminines. d'autres gazetiers insistent sur les clameurs des femmes et leur violence autant physique que verbale. Ainsi, Mercurius Civicus affirme que les exécrations féminines conduisent logiquement à l'affrontement avec les forces de l'ordre:

the greatest part of themselves carrying themselves very uncivilly towards divers Members of the House. and others using many horrid execrations. that they would have the blood of those (whom in their furious zeale conceived to be averse to peace) so that at last from words they fell to blowes. insomuch that upon their insolent abusing of divers men of quality, the trained Band and two troops of Horse were forced to fall amongst them for feare of further danger: but they continuing their outragious courses in casting stones and brickbats. they occasioned the more violence to be used against them. wherein divers of them were dangerously hurt. and two men and two women slaine. and at last upon the riding of the Troopers with their horses among them. they were totally scattered. ${ }^{20}$

Enfin, les gazettes les plus dévouées à la cause du Parlement vont jusqu'à nier la responsabilité des femmes dans ces manifestations qui

18. Sur ce thème voir Ronzeaud, "De la harengère à la 'harengeuse': Étude d'un stéréotype polémique forgé au XVIle siècle." Ouverture et dialogue: Mélanges offerts $\dot{a}$ Wolfgang Leiner (Tubingen: Gunter Narr, 1988) 739-53. On peut aussi se reporter à Sara J. Eaton, "Presentation of Women in the English Popular Press," Ambiguous Realities: Women in the Middle Ages and the Renaissance, ed. Carole Levine and Jeanie Watson (Detroit: Wayne State UP, 1987) 165-83.

19. The Kingdomes Weekly Intelligencer (8-15 August 1643): 229. La basse extraction des femmes est aussi mentionnée dans Certaine Informations (7-14 August 1643): 231 ("Yesterday in the afternoone, two or three hundred Oyster wives, and other dirty and tattered sluts, tooke upon them the impudency to come to the Honourable House of Commons and cried for Peace and Propositions"). On retrouve des qualificatifs similaires au sujet des femmes Niveleuses dans Mercurius Pragmaticus (23-30 April 1649): sig. $\mathrm{Al}^{\circ}$.

20. Mercurius Civicus (3-11 August 1643): 88. 
auraient été entièrement orchestrées par les hommes: à les en croire, les partisans de la paix manipulent les femmes révoltées pour effrayer l'adversaire. C'est le Weekly Intelligencer qui donne l'analyse la plus complète de ce complot masculin: "The Malignants upon this consulted what to doe, to worke their ends, by possessing the people. . . : They that Munday night . . . put on those Women that were Ring-leaders of the crew to get such women in and about the city of London and the suburbs as were desirous of Peace." 21 Le journaliste ajoute encore que ce sont des hommes qui poussent les femmes à continuer leur révolte: "besides the men Malignants who were amongst them . . . clapt them on their backes and bid them not to be afraid, but to go on." ${ }^{22}$ Un commentateur insinue même que des hommes déguisés en femmes se sont mêlés à la foule des manifestantes: "And some in the Rabble mixing among 'em and instigating 'em." ${ }^{23}$ Natalie Zemon Davis. auteur d'une typologie passionnante de ces phénomènes d'inversion, explique que ce genre de travestissement est une pratique relativement commune dans les mouvements d'émeute: ${ }^{24}$ la femme révoltée, effrénée est un puissant symbole de rébellion pour qui sait bien l'utiliser.

Ces procédés qui consistent à dégrader l'action des pétitionnaires sont utilisés beaucoup plus systématiquement et plus uniformément dans des parodies de pétitions féminines où l'enjeu politique des revendications est cette fois complètement occulté. ${ }^{25}$ Les auteurs de ces pamphlets vont encore plus loin dans la caricature. Ils mettent en scène des femmes qui assument pleinement les accusations traditionnelles dont elles sont depuis toujours les victimes - grossièreté, lubricité et bassesse - afin de faire rire et de réduire leur intrusion sur la scène publique à un renversement de carnaval. ${ }^{26}$

21. The Kingdomes Weekly Intelligencer (8-15 August 1643): 228.

22. The Kingdomes Weekly Intelligencer (8-15 August 1643): 229.

23. John Rushworth, Historical Collections 15 (1708): 143.

24. Natalie Zemon Davis, "Women on Top," Society and Culture in Early Modern France (Stanford: Stanford UP, 1975) 124-51.

25. Voir Brian Patton. "The Women Are Revolting? Women's Activism and Popular Satire in the English Revolution," Joumal of Renaissance and Medieval Studies 23 (1996): 70-87; Diane Purkiss, "Material Girls: The Seventeenth-Century Woman Debate," Women Texts and Histories 1575-1760, ed. Purkiss and Clare Brant (London: Routledge, 1992) 83-84.

26. L'étude de Mikhaïl Bakhtine. L'Euvre de François Rabelais et la culture populaire au Moven Age et sous la Renaissance (Paris: Gallimard, 1976), offre des pistes intéressantes pour l'étude de ces textes. Il faut noter que les procédés de ventriloquisme utilisés dans ces parodies de pétitions viennent tout droit des ballades. Sur ce sujet, voir Joy Wiltenburg, Disorderly Women and Female Power in the Street 
Prenons quelques exemples. En 1643 paraît une pétition parodique qui fait directement écho aux pétitions réelles des femmes de Londres pour la paix. Son titre complet est le suivant:

The Humble Petition of Many Thousand Wives and Matrons of the City of London. and Other parts of the Kingdome. For the Cessation and Finall Conclusion of these Civill Wars. And for the Restitution and Revocation of their Husbands. Who have as just cause to complaine for want of them. together with our children and bosom friends. as the Virgins have for losing their Sweet-hearts. Presented by Divers Gentlewomen of Good Credit and Citizens Wives. To the consideration of both Houses. On Thursday. the second of February.

On trouve dans ce titre toutes les caractéristiques formelles du document officiel mais le contenu montre que l'appel à la paix est réduit à des considérations purement matrimoniales et sexuelles. Pour elles, la guerre représente avant tout une pénurie de maris. comme le montre ce passage de la Humble Petition:

We poor soules wander like solitary Turtles without mates: not one man among a hundred. since the departure of the Courtiers and Cavaliers, that in this City hath so much honesty as to ask a married woman the question. or offer his body to her service: and if this be not a lamentable case my Masters. you who have Wives. and so know what belongs to Women. be impartiall and just Judges. All the flesh is fraile we know, and we women are the weaker vessels. and so have the frailer flesh. and the more subject to our failings then Men. ${ }^{2 ?}$

On retrouve les mêmes techniques satiriques dans une parodie de pétition niveleuse intitulée $A$ Remonstrance of the Shee-Citizens of London. And of Many Thousands of Other Free-Borne Women of England, publiée en 1647, date à laquelle les revendications politiques des femmes Niveleuses commencent à prendre forme.$^{28}$ Le mot "remonstrance" fait bien sûr allusion à la "Great Remonstrance" de 1641 qui recensait les griefs du Parlement contre Charles Ier. La rhétorique de ce pamphlet parodique, quant à elle, est empruntée aux écrits niveleurs: les femmes insistent sur leurs droits et leurs libertés en se présentant comme "[the] assistants and the co-equalls of the famous citizens of London" et se plaignent de

Literature of Early Modern England and Germany (Charlottesville: UP of Virginia, 1992) $48-49$.

27. The Humble Petition of Many Thousand of Wives and Matrons . . . for the Cessation of These Civill Wars (London, 1643) 5 [STC 3475].

28. [STC R6014]. 
l'asservissement dans lequel elles sont tombées: "a strict subjugation of us the free-borne women of England."29 Mais toute cette belle éloquence est dégradée par une description de Niveleuses lubriques et gourmandes qui aspirent au retour des Cavaliers et du roi. synonymes pour elles de tous les plaisirs:

We conceive no way conducing more to our desire then that his Majestie speedily come to London, there to reside with honour and safetie: for let us the world know. to our unspeakable grief, we have these many years missed the societie of his retainers, those embroidered Courtiers . . . when we were coacht jogging to Mile-end. Islington, and Braineford. stuffing our bellies with cakes. and creame. and while our husbands. good men. were either handselling their wares. or cancelling their bonds. not dreaming that we also were bartering their commodities for our best advantage: we therefore desire. that his Majestie may with all speed repaire to London. as the primary ways for us to attain our wishes. $^{30}$

La meilleure façon de comprendre la nature du rire cathartique que cherchent à susciter ces textes est. nous semble-t-il, de le rapprocher de celui provoqué par d'autres pratiques populaires. en particulier le charivari, qui visait généralement. à travers un rituel de désordre et le rire de toute la communauté. à punir la domination abusive de la femme sur son mari et, par là, à rétablir le cours normal des choses. ${ }^{31}$ Cette fonction du charivari est très bien décrite par Marvell: "A punishment invented first to awe / Masculine Wives transgressing Nature's Law." ${ }^{32}$ Dans ce sens, les pétitions scabreuses seraient, outre le prétexte à une sempiternelle satire des femmes,

\section{Remonstrance 2}

30. Remonstrance 4. Parmi les nombreuses parodies de pétitions publiées surtout dans la décennie 1640, on peut encore citer The Petition of the Weamen of Middlesex (London, 1641) [STC P1838], The Mid-wives Just Petition; or, A Complaint of Divers Good Gentlewomen of That Faculty (London, 1642) [STC M2005]; The Virgins Complaint for the Losse of Their Sweet-Hearts (London, 1642) [STC V640]; The Widowes Lamentation for the Absence of Their Dear Children, and Suitors (London, 1643) [STC W2093]: The l'irgins Complaint for the Losse of Their Sweet-Hearts (London, 1642) [STC V640].

31. Des spécialistes de ces pratiques populaires ont également rapproché des charivaris les mocking-rhymes que l'on chantait sous les fenêtres de ceux qui avaient transgressé le bon ordre conjugal, et aussi les ballades populaires qui ne se lassent pas de tourner en ridicule toutes les formes de déviances domestiques. Voir Elizabeth Foyster, "A Laughing Matter? Marital Discord and Gender Control in SeventeenthCentury England," Rural History 4.1 (1993): 5-21.

32. Andrew Marvell, "Last Instructions to a Painter" (1.372-89), The Poems and Letters of Andrew Marvell, ed. H. M. Margoliouth, 2 vols. (Oxford: Clarendon, 1927) 1: 150. 
le moyen de renforcer les valeurs de l'ordre patriarcal. ${ }^{33}$

Toutefois, malgré les nombreux éléments de parodie qui invitent d'abord à lire ces pamphlets comme des satires contre les femmes, on ne peut s'empêcher de leur donner une dimension politique qui rend le rire libérateur moins simpliste et plus ambigu qu'il n'y parait d'abord ${ }^{34}$ Ainsi, dans The Humble Petition dont nous avons déjà cité un extrait, la rhétorique niveleuse, détournée de sa véritable fonction. sert paradoxalement à défendre la cause du roi: derrière les propos vulgaires des prétendues auteurs de la pétition, perce la voix d'un royaliste sincèrement nostalgique de la "merry old England":

In consideration of all which grievances and oppressions which fall daily and nightly upon us. we the good wives and bad wives. chaste and unchaste. Scolds and Turtle-doves, being of the number of at least three millions of bodies throughout the whole Kingdome: most humbly intreat. and with teares in our eyes. beseech that an end may be suddenly put to these bloudy and desperate civill warres. wherein so much blood hath been shed. to the terrour of all Christian people. especially of us weake and tender-hearted women:... that we may againe bring forth children every yeare to increase the number of the Kings liege people and faithfull Subjects. And we as in all duty bound shall ever pray. \&c. ${ }^{35}$

C'est aussi dans un sens royaliste que l'on peut lire The City Dames Petitions de 1647 dans laquelle les femmes Têtes Rondes aspirent pour des raisons à la fois triviales et de bon sens au retour du roi et de la cour.

Ce qui apparaît en tout cas dans ces pétitions apparemment anodines et dans les gazettes par lesquelles nous avons commencé notre étude, c'est une relation de contiguitté entre une féminité débridée et dominatrice et la

33. Sur le charivari, voir James Sharpe, "Plebeian Marriage in Stuart England: Some Evidence from Popular Literature," Transactions of the Roval Historical Society 36 (1986): 80)-90: David Underdown, Revel. Riot and Rebellion. Popular Politics and Culture in England 1603-1660 (1985: Oxford: Oxford UP, 1987) 99-103; Martin Ingram, "Ridings, Rough Music and Mocking Rhymes in Early Modern England," ed. Barry Reay (London: Croom Helm, 1985) 166-97. Sur la nature du rire provoqué par les charivaris et d'autres formes de parodie populaire, voir Keith Thomas, "The Place of Laughter in Tudor and Stuart England," TLS January 21 (1977): 77-79.

34. Sur les problèmes d'interprétation que pose le motif de l'inversion, voir Peter Stallybrass, "The World Is Turned Upside Down: Inversion, Gender and the State," The Matter of Difference: Materialist Feminist Criticism of Shakespeare, ed. Valerie Wayne (New York: Harvester Wheatsheaf, 1991) 204-05.

35. The Humble Petition 8. 
crise politique qui touche toutes les institutions de la monarchie anglaise. C'est ici encore une manifestation du lien fondamental qui existe dans les mentalités au milieu du XVIIe siècle entre l'ordre domestique et l'ordre politique. Dans cette perspective, la peur d'une dislocation des hiérarchies fondées sur le sexe trahit l'angoisse d'une décomposition de l'État: la dénonciation des pétitionnaires débouche en fait sur une critique du pouvoir.

Mais l'extension du motif d'inversion sexuelle dépasse les enjeux finalement limités de l'activisme féminin des années 1640: les pamphlets que nous allons étudier à présent continuent à ne parler que des femmes et des dangers qu'elles représentent pour l'ordre social: mais ici l'inversion des sexes est avant tout une arme polémique aux visées essentiellement politiques.

Les royalistes considèrent toute forme de résistance au monarque comme une inversion des valeurs. Le Parlement met décidément la charrue avant les bœufs: "All things are turn'd the clean contrary way; / The world's turned upside down, from bad to worse / Quite out of frame, The cart before the horse. ${ }^{136}$ De nombreuses satires, royalistes ou niveleuses, qui prennent souvent la forme de petites pièces de théâtre, se servent du motif de l'inversion sexuelle pour critiquer cette perversion des valeurs. Les épouses des leaders de l'armée sont parmi leurs cibles favorites, en particulier en 1648 et 1649. La fin du pamphlet The Cuckoo's Nest at Westminster met sur le devant de la scène Queen Fairfax et Lady Cromwell, les deux épouses des grands généraux de la New Model Army, décrites grâce aux stéréotypes de la femme dominatrice et dépravée. En montrant ces deux harpies défendant bec et ongles les droits de leurs maris à devenir rois d'Angleterre, le satiriste sous-entend que les généraux, considérés comme des héros par leurs partisans, sont soumis aux désirs ambitieux de leurs femmes qui ne désirent rien d'autre que devenir reines à la place de la reine. Il met aussi en cause la vertu républicaine que cherchait à incarner les généraux: la cause du régime est tombée entre les mains de harengères:

Qu. Fairfax. Pray Mrs. Cromwell, tell not me of Gowns or lace, nor no such toyes? Tell me of Crownes. Scepters. Kingdomes, Royall Robes, and if my Tom ... thrives in his Enterprise. I will not say Pish to be

36. John Taylor, Mad Fashions, Od Fashions, All out of Fashions; or. The Emblems of These Distracted Times (London, 1642). Le même texte, à peine mis à jour, réapparaît dans The World Turn'd Upside Down de 1647, signé par les initiales J. T. [STC J1072A]. 
Queen of England; I misdoubt nothing. if we can keep the wicked from fetching Nebuchad-nezzar home from Grasse in the Isle of Wight: well. well my Tom is worth a thousand of him. and has a more kingly Countenance: He has such an innocent face, and a harmless look. as if he were borne to be Emperour over the Saints.

Mrs. Crom: And is not Nolls Cromwells Wife as likely a Woman to be Queen of England as you? Yes I warrant you is she: and that you shall know, if my Husband were once come out of Wales. 'tis he that had done the Work; the Conquest belongs to him: besides your husband is counted a Fool, \& wants witt to Reigne; everybody scoffs at him: my Noll has a headpiece, a face of brass (full of Majesty) and a Nose will bright the whole Kingdome to walke after him. . . . As for myself I have a person fit for a Queen as another.

Ou. Fair. Thou a Queen: a Quean? ... hold your clack from prating Treason against me. or Ile Make Mrs. Parliament lay her Ten Commandments upon thee? thou a Queen: a Brewers Wife a Queen: that Kingdom must need be full of drunkards, when the king is a brewer? My Tom is nobly descended, and not a Mechanick.

Mrs. Crom. Mechanick? Mechanick in thy face: th 'art a Whore to call me a Mechanick: I am no more Mechanick then thyself . . Queen? Yes you shall: Queen of Puddle Dock or Billings-gate. . . .

On retrouve le même genre de satires pendant les années de confusion qui vont de la mort d'Oliver Cromwell en 1658 à la Restauration. Une piccc de John Tatham, The Rump: or. Mirrour of the Late Times, reprend le thème des épouses avides et ambitieuses pour stigmatiser la corruption et la vilenie du régime. ${ }^{38}$ À travers la mise en scène des rivalités et des disputes mesquines de Lady Lambert, Lady Fleetwood et Mrs. Cromwell, Tatham condamne les noirs desseins des prétendants au pouvoir. ${ }^{39}$

37. [Mercurius Melancholicus], The Cuckoo's-nest at Westminster; or; The Parliament between the Two Lady-birds, Quean Fairfax, and Lady Cromwell (London, 1648) 7-8. Voir aussi des scènes similaires dans The Kentish Fayre; or. The Parliament Sold to Their Best Worth ([London], 1648) [STC K324], [The Man in the Moon], A TragiComedy, Called New Market Fayre; or, A Parliament Outcry of State Commodities, Set to Sale (London, 1649) 4-5 [STC T2019].

38. Iohn Tatham, The Rump; or, The Mirrour of the Late Times (London, 1660), reproduit dans The Dranatic Works of John Tatham, ed. James Maidment and W. H. Logan, 1874 (New York: Benjamin Bloom, 1967) 189-284. La pièce fut probablement jouée avant la chute du Rump en février 1660.

39. Ces femmes sont l'objet de nombreuses satires. On peut lire par exemple To His Excellency General Mlonck: The Humble Petition of Lady Lambert (London, [1659]), A Curtain-Conference Being a Discourse betwixt - John Lambert Esq. And His Lady (London, 1659), The Case Is Altered; or, Dreadful News from Hell (London, [1660]) [STC C871]. 
Visiblement, le souci de la raison d'État n'embarrasse pas beaucoup ces leaders entièrement dévoués aux passions de leurs femmes. Le rire est ici destiné à dévoiler la bassesse et l'illégitimité d'un régime populaire et à réaffirmer, par différence, la noblesse des valeurs de la monarchie. ${ }^{+1}$

Les royalistes sont loin d'avoir le monopole de ce genre de satire; on retrouve en effet des procédés similaires dans trois pamphlets publiés en 1647 et attribués au républicain Henry Neville, traducteur de Machiavel et ami de Harrington. ${ }^{41}$ Dans ces pamphlets qui reprennent le motif aristophanesque de l'assemblée des femmes ${ }^{42}$ le motif de l'inversion sexuelle est utilisé pour faire une impitoyable satire de la cause royale. Ainsi, dans An Exact Diurnall of the Parliament of Ladyes. les partisans du roi sont jugés sévèrement par un tribunal de femmes royalistes - celles-là mêmes qui sont censées les soutenir - qui leur infligent un châtiment proportionné à leurs crimes: Sir Henry Jermyn, naguère grand intrigant à la cour, est ainsi condamné à démêler les complots que les hérons et les grues fomentent contre les Pygmées: "The Lord Henry Germin, his judgment is to be confined to the land of Pigmyes to help the Inhabitants to discover the suttle plots of the Cranes and Herons; and assert them against such like same Birds that would eat them up." ${ }^{43} \mathrm{La}$ trame des deux autres Parlements de 1647, The Parliament of Ladies et la suite. The Ladies. A Second Time Assembled in Parliament, reprend l'ordre du jour de la procédure parlementaire: plaintes, griefs, proclamation des ordonnances. On a même, comme dans la réalité du temps, des jeûnes, des jours d'actions de grâces et d'humiliation, et aussi des sermons. Toutefois, ce cadre historique et législatif qui laisse croire à une véritable initiative politique des femmes n'est qu'un leurre puisque les préoccupations matérielles et

40. Voir notamment $2.1,3.1$ et 5.1 . Dans la première édition, la plupart des noms des protagonistes sont inversés: Lady' Bertlam, Lady Woodfleet, etc.

41. Sur ces écrits satiriques de Neville, voir Nigel Smith, Literature and Revolution in England, 1640-1660 (New Haven: Yale UP, 1994) 47-49; Susan Wiseman, "'Adam, the Father of all Flesh,' Pomo-Political Rhetoric and Political Theory in and after the English Civil War," Pamphlet Wars, Prose in the English Revolution 134-57. Ce theme a inspiré d'autres satiristes. Voir à ce sujet: Women and the Literature of the Seventeenth Century: An .Annotated Bibliography Based on Wing's Short-Title Catalogue, ed. Hilda L. Smith and Susan Cardinale (New York: Greenwood P, 1990).

42. Voir en particulier, Lysistrata, Les Thesmophories, L'Assemblée des fenmmes dans Aristophane, Théatre Complet II, ed. Victor-Henry Debidour (Paris: Gallimard, 1966)

43. [Henry Neville], An Exact Diumall of the Parliament of Ladyes ([London], 1647) 8 [STC N504]. L'idée d'une lutte entre les Pygmées et les grues, qui peut paraitre saugrenue, remonte à une légende au moins attestée depuis Homère: on trouve l'évocation du complot au début du Chant 3 de l'Iliade. 
sexuelles l'emportent en fait. Dans The Parliament of Ladies, par exemple, le discours puritain sur l'idolâtrie devient dans la bouche des femmes le prétexte à une défense du maquillage:

Soon after the Lady Norton. door keeper of the House, complained of Sir Robert Harlow, a member of the House of Commons, for attempting to deface her. which hapned thus, the said Lady being a Zealous Independent, and so one of the Saints, and Sir Robert having found that she was likewise painted, he pretended that he came with his Ordinance of Idolatry. Saints. Crosses. \&c. But some friends of the Lady door keeper. urging on her behalfe. that none did ever yet attempt to adore her or worship her. she was justified. and the House then declared that if any person by vertue of any power whatsoever. pretended to be denied from the House of Commons. or any other Court, shall go about to impeach, hinder, or disturbe any Lady, from painting, washing or adorning herself to the best advantage, as also from plaiting of her hair, or vesting her Teeth. that, that act is a great breach of the priviledge of the House. and that the offenders shall be prosecuted against accordingly. ${ }^{44}$

Dans The Ladies. A Second Time Assembled in Parliament. les sujets les plus sérieux comme la redistribution des terres des évêques sombrent dans de futiles affaires d'alcôve:

In the first place they tooke into consideration. the sale of the Bishops Lands. and upon the Question resolved:

That the Bishopricke of Lincolne. of Worcester, of Ely, and Durham, should remayn intire: for that though the Bishops of those Sees. had in other matters of concernment. showed themselves very averse, yet to the ladies assembled. they had been very free and cordiall, even to their utmost abilities. and had in some private performances. ayded them more strongly than any secular man whatsoever..$^{45}$

Toutefois, ce n'est pas simplement une critique somme toute conventionnelle du règne des femmes que nous fournit Neville à travers de tels passages; les références constantes à l'actualité et à des personnes réelles sont bien plutôt le signe que le gouvernement féminin renvoie directement, comme à travers un miroir déformant, aux pratiques dévoyées et corrompues de leurs homologues masculins. Le motif de l'assemblée des femmes ne serait en ce sens qu'une stratégie rhétorique pour mieux mettre

44. [Henry Neville], The Parliament of Ladies; or, Divers Remarkable Passages of Ladies in Spring-Garden; in Parliament Assembled (London, 1647) 11.

45. [Neville], The Ladies. A Second Time Assembled in Parliament. A Continuation of the Parliament of Ladies ([London], 1647) 2 [STC N507]. 
au jour l'incapacité des hommes à gouverner; car, dans ce monde où toutes les valeurs sont inversées, ce n'est qu'en représentant le réel sur le mode de l'inversion (ici l'inversion sexuelle) que l'on peut en faire jaillir la vérité: comme le dit Gracian: "on ne saurait bien voir les choses du monde qu'en les regardant à rebours. ${ }^{46}$ L'inversion sexuelle est ainsi un outil qui sert non seulement à dénoncer mais aussi à comprendre la guerre civile. Il ne faudrait pas prendre trop à la légère la portée subversive de ces textes; on aurait tort d'y voir de simples productions alimentaires répétant jusqu'au dégoût de vieux thèmes misogynes et aristophanesques: l'humour est ici corrosif et idéologique. L'auteur de Match Me These Two a d'ailleurs bien compris la véritable cible de ces pamphlets en apparence inoffensifs. Pour lui, les discours dépravés et futiles des femmes portent directement atteinte à l'institution du Parlement, objet dans ces grossières brochures de la plus abjecte diffamation: "Rowing one way, and looking another, he [the author of the Parliament of Ladies] had revil'd, despis'd \& jeer'd even the Parliament of England, questioning their Orders in Dark Speeches, censuring their Actions under feigned names, and deriding their persons by a wilfull mistake." ${ }^{47}$ Dans ce sens, ces parlements de femmes sont emblématiques de tout ce que Neville, anti-religieux autant qu'anti-royaliste, abhorre. Certes, les royalistes sont les premières victimes de sa calomnie mais il attaque aussi les transfuges, jadis amies de la reine, qui ont rejoint la cause parlementariste dans la guerre civile. ${ }^{48}$ Ainsi, c'est toute la cour Stuart dégénérée et déchirée par les coteries qui tombe sous le coup de la critique féroce de Neville. ${ }^{49}$ La transgression de l'ordre patriarcal qu'il met

46. Qtd. in Jean Rousset, La Littérature à l'àge baroque. Circé et le paon (Paris: José Corti, 1954) 24.

47. Match me these Two; or; The Conviction and Arraignment of Britannicus and Lilbume with an Answer to a Pamphlet Entitled. The Parliament of Ladies (London, 1647) 13 [STC M1077]. Dans New Newes from the Old Exchange [STC N687], un pamphlétaire réagit à un autre "parlement de femmes," attribué à Neville (Newes from the New-Exchange; or, The Commonwealth of Ladies, Drawn to Life [London, 1650] [STC N510]), et se plaint de l'inversion systématique des valeurs que cette nouvelle satire fait subir aux valeurs traditionnelles: "Good God! what an unexpected exchange of all things do we live to see?" (New Newes 2).

48. Voir les deux assemblées qui se succèdent dans The Ladies. A Second Time Assembled in Parliament: la première est composée de Cavaliers tandis que la seconde est essentiellement constituée de femmes de l'aristocratie qui ont rallié la cause puritaine.

49. Les factions à la cour de Charles Ier que critique Neville sont très bien décrites par Brian Manning, "The Aristocracy and the Downfall of Charles I," Politics, Religion and the English Civil War, ed. Manning (London: Edward Amold, 1973) 37-80. Voir aussi R. Malcom Smuts, "The Puritan Followers of Henrietta Maria in the 1630s," English Historical Review 93 (1978): 26-45. 
en scène dans ces assemblées renvoie l'image inversée d'un régime fondé sur la virtù républicaine tel que Neville, lecteur de Machiavel, pouvait le rêver. $^{\text {so }}$

Mais le motif de l'inversion sexuelle n'est pas seulement utilisé comme un indice de corruption du pouvoir masculin ou comme une arme polémique pour fustiger l'adversaire. Pour les royalistes qui ne cessent de déplorer le désordre, la voix de la commère gourmande, bavarde et tyran domestique est pour eux un moyen paradoxal de donner leur version dc la verité des temps. En effet, dans des temps de folie, seule la voix du bouffon - ici la femme - peut dire la vérité.$^{51}$ On pense à Érasme qui faisait de la folie la figure féminine par excellence: "la femme a beau mettre un masque, elle reste toujours femme, c'est-à-dire folle," écrit-il. ${ }^{52}$ De même, c'est tout en se plaignant de la confusion des temps que, dans The Gossips Feast: or. Morall Tales de joyeuses commères affranchies de toute autorité masculine vont dire ce qui aux yeux du pamphlétaire constitue la vérité ultime: ${ }^{53}$ la victoire prochaine du roi et le retour aux traditions de la "merry old England." ${ }^{54}$ C'est parce que le monde est fou que seule la parole affolée approchera la vérité et que Gammer Grumble pourra chanter l'histoire de l'Angleterre jusqu'à l'emprisonnement du roi à l'île de Wight:

Gammer Grumble having taken a hearty draught of ale began to sing, When as the chiefest of things were in handling,

Order and Discipline puld to the ground,

And base Hypocrisie Rebellion dandling,

Fooles walking at large, wise men in the pound:

50. Sur la critique républicaine d'une cour corrompue, voir Stallybrass, "The World is Turned Upside Down" 206-09.

51. Pour une étude de la folie dans la littérature pamphlétaire, voir Jonathan Sawday, "'Mysteriously Divided': Civil War, Madness and the Divided Self," Literature and the English Civil War, ed. Thomas Healy and Jonathan Sawday (Cambridge: Cambridge UP, 1990) 127-43.

52. Érasme, Éloge de la folie, 1511 (Paris, Flammarion, 1974) 28.

53. The Gossips Feast; or, Morall Tales (London, 1647) [STC G1316]. Sur le motif des réunions de commères, voir Linda Woodbridge, Women and the English Renaissance. Literature and the Nature of Womankind 1540-1620 (Urbana: U of Illinois P, 1984) 22425; Sharpe, "Plebeian Marriage in Stuart England: Some Evidence from Popular Literature," Transactions of the Royal Historical Society 36 (1986): 80-82; Alexander Rysman, "How the 'Gossip' Became a Woman," Journal of Communication 27.1 (1977): 176-80.

54. L'auteur n'hésite pas à dire que ces commères sont ses porte-parole: "such plaine creatures as these by whom I speak" (The Gossips Feast sig. A2). 
When as toads flew, and Eagles did crawle,

Loe a hand was put forth

For to save those of worth,

Hell shreikt.

Knaves squeikt

Fearing to fall. ${ }^{\text {ss }}$

Il demeure que pour Gammer Grumble le monde à l'envers n'a pas le dernier mot. En effet l'emprisonnement de Charles à l'île de Wight trouve dans son histoire une issue aussi favorable qu'improbable: les troupes parlementaires, divisées et saisies de remords, décident de remettre triomphalement le roi sur son trône.

À côté de cette figure inoffensive de la commère, on trouve dans l'imaginaire de la Révolution anglaise l'image plus inquiétante de l'hermaphrodite. Certes les peurs que nourrit la confusion du masculin et du féminin n'est pas nouvelle: il suffit de penser à la controverse jacobéenne autour de la mode vestimentaire féminine qui consistait à porter un chapeau à larges bords, un poignard et un pourpoint très court. ${ }^{56}$ L'auteur du pamphlet le plus hostile à cette mode, Hic Mulier; or, The Man-Woman, gratifiait d'ailleurs ses adeptes du titre de "new hermaphrodites." ${ }^{57}$ Mais l'indistinction des genres prend pendant la Révolution une dimension symbolique nouvelle en renvoyant désormais au désordre des temps et à la colère de Dieu. Ainsi, la fin du pamphlet The Parliament of Ladies interprète la naissance monstrueuse d'un être androgyne comme un présage de la fin des temps toute proche. L'histoire est désormais bouclée: cet événement annonce le retour à l'Adam originel, androgyne avant la création de la femme; la fin du monde n'est que le reflet inversé et monstrueux de son début: ${ }^{58}$

This day there was a commotion in the House, by reason of a disorder in the City, occasioned by a rumor of Doomsday, which, the people did believe was at hand, and that the World was now ending, because it had met with its beginning, for Adam and Eve were seen both in one person, and whereas Eve was once taken out of Adam, Adam was now

55. Gossips Feast 8.

56. Pour cette controverse voir Woodbridge, Women and the English Renaissance $139-51$

57. Le pamphlet est reproduit dans Katherine Usher Henderson, Half Humankind: Contexts and Texts about Women in England (1540-1640) (Urbana: U of Illinois P, 1986) 265-76.

58. Voir Genèse 2.23: "she was called Woman because she was taken out of man." 
seen strutting out of Eve. ${ }^{59}$

La vie de Mary Frith alias Moll Cutpurse, personnage à la fois réel et mythique, fournit au préfacier de son autobiographie, publiée en 1662 , l'occasion de rapprocher une fois encore la confusion des sexes et le désordre politico-religieux des années 1640-1660. ${ }^{60}$ Habillée en homme, portant l'épée et fumant la pipe, impliquée dans des activités de recel et de brigandage, Moll est "an Hermaphrodite in Manners as well as in Habit" ct sa vie doit s'interpréter comme un prodige envoyé par les dieux pour signifier le désordre des temps:

Such people shall yet give us the liberty to take her for a Prodigy of those Times she lived in, and be altogether as presagious in her Habit and Manners. as they [the sibyls] were in their ambiguous and doubtfull sentences. ...

Our angry Fates doe sometimes dispence and afford us more familiar and near Hints and Omens of their displeasure . . . in the strange yet ridiculous corruptions and indispositions of humours, which they perspicuously manifested in this Epicoene Wonder. . . .

She was the Living Discription and Portraiture of a Schism and Separation. her Doublet and Petticoate, understanding one another no better than Presbytery and Independency, and as it was wondred by some. that in imitation of the latter, and in honour of the Rump she wore not the Breeches, but it seems she was Loath to innovate in her Olde Years. ${ }^{61}$

Symboliquement donc, la mort de Moll, qui survient au moment de la Restauration, signifie la fin de la période désastreuse de l'Interrègne. La disparition de l'hermaphrodite coïncide donc avec la remise en ordre de l'Histoire, comme si restauration monarchique et différenciation sexuelle étaient inséparables.

59. The Parliament of Ladies 13. On pense ici aux nombreux récits de naissances monstrueuses qui circulent dans les pamphlets, y compris dans les gazettes. Voir par exemple, A Declaration of a Strange and Wonderful Monster (London, 1646) [STC D603], et $A$ Strange and Lamentable Accident That Happened Lately at Mears Ashby in Northamptonshire (London, 1642) [STC 5819].

60. Ce personnage apparaît à plusieurs reprises dans les parlements de Neville sous les traits du "sergeant-at-arms." Elle est l'héroïne de plusieurs pièces dont la plus connue est The Roaring Girl de Dekker et Middleton, publiée à Londres pour la première fois en 1611 .

61. The Life and Death of Mrs. Mary Frith. Commonly Called Mal Cutpurse, Exactly Collected and Now Published for the Delight and Recreation of All Merry Disposed Persons (London, 1662) ("To the Reader"). Reproduit dans Counterfeit Ladies, ed. Janet Todd and Elizabeth Spearing (London: Pickering, 1994) 3-4. 
Ainsi, ce que nous montre la lecture de ces quelques exemples, c'est l'impossibilité de penser la différence autrement que sur le mode de l'inversion. La différence sexuelle tout d'abord, puisque les pétitionnaires ne pourront jamais prendre la parole en tant que femmes, mais toujours en tant qu'hommes ratés dont les propos ne seront jamais pris au sérieux. L'opposition politique ensuite, puisqu'on ne voit en l'adversaire que le reflet inversé de ses propres valeurs: dans le camp adverse où tout marche à l'envers, ce sont aussi les femmes qui gouvernent. Cette structure contraignante ne permet pas, on s'en doute, de penser la réalité de la guerre civile avec toutes les nuances qui seraient nécessaires: il resterait en particulier à écouter ces voix féminines infiniment plus riches que ne le laissent croire la plupart des pamphlets. Mais ce que nous révèlent ces inversions systématiques, c'est une attitude mentale caractéristique de la Révolution anglaise, et qui n'est pas sans lien avec ce que certains, à l'instar de Gérard Genette, appellent le baroque:

Peut-être aussi ne faut-il lire à travers cet ingénieux système d'antithèses, de renversements et d'analogies qu'un conflit entre la conscience aiguë de l'altérité, qui obsède cette époque, et son impuissance à la concevoir autrement que sous les espèces d'une identité pervertie, ou masquée. Infirmité peut-être congénitale de l'imagination, qu'on retrouverait aussi bien ailleurs, mais qui fournit au Baroque le principe même de sa poétique. ${ }^{62}$

Claire GHEERAERT-GRAFFEUILLE Université de la Sorbonne Nouvelle - Paris III

Communication présentée au Congrès de la SAES, Rennes, mai 1998

62. Gérard Genette, "L'Univers réversible," Figures I (Paris: Le Seuil, 1969) 22. 